Tersedia online di: http://ejournal-balitbang.kkp.go.id/index.php/jra

\title{
PERBAIKAN MUTU GENETIK IKAN MAS RAJADANU MELALUI SELEKSI
}

\author{
Deni Radona\#, Sidi Asih, Jojo Subagja, dan Rudhy Gustiano \\ Balai Penelitian dan Pengembangan Budidaya Air Tawar
}

\begin{abstract}
ABSTRAK
Ikan mas rajadanu mempunyai karakter cepat tumbuh dan tahan penyakit. Selective breeding merupakan salah satu upaya dalam peningkatan mutu induk dan benih. Penelitian ini bertujuan untuk melihat respons pertumbuhan dan nilai heritabilitas pada ikan mas rajadanu (F-3) yang berpotensi tumbuh lebih cepat dibandingkan dengan generasi sebelumnya (F-2). Pembentukan ikan mas rajadanu F-3 dilakukan dengan metode hierarki (satu jantan membuahi empat betina). Pengujian respons seleksi dilakukan terhadap benih hasil pemijahan induk ikan mas rajadanu F-2 yang terseleksi. Terbentuk sebanyak 25 famili dan dipelihara secara terpisah selama 160 hari pada kolam beton ukuran 1,5 m x $1 \mathrm{~m}$ dengan ketinggian air $60 \mathrm{~cm}$. Kolam digunakan sebanyak 25 buah. Respons seleksi dihitung dengan melihat nilai rata-rata pertumbuhan F-3 dibandingkan dengan F-2. Hasil penelitian menunjukan performa ikan mas rajadanu F-3 memiliki nilai respons seleksi (14,20 g); nilai heritabilitas (0,60); pertambahan bobot $(41,63 \pm 10,51 \mathrm{~g})$; dan pertambahan panjang $(9,86 \pm 1,43 \mathrm{~cm})$.
\end{abstract}

KATA KUNCI: rajadanu; heritabilitas; respons; pertumbuhan; genetik gain

ABSTRACT: Improvement of the genetic quality carp rajadanu through selection. By: Deni Radona, Sidi Asih, Jojo Subagja, and Rudhy Gustiano

Rajadanu carp strain have character of fast growing and disease resistant. Selective breeding is one of an attempts can be appllied to improve the broodstock and seed quality genetically. This research was aims to see response of growth and heritability value of F-3 on carp rajadanu that potentially grow faster compared with previous generation (F-2). The F-3 carp rajadanu was designated with hierarchy method (one males fertilize four female). The F-3 was derived from F-2 and formed 25 families. Those families were maintained for 160 days on pond with size of $1.5 \mathrm{~m} \times 1 \mathrm{~m}$ and water depth of $60 \mathrm{~cm}$. The response selection was calculated by choosing the best individuals of each based on ADG (averange daily growth). The research result show that the values of response selection was $14.20 \mathrm{~g}$, heritability value of 0.60, weight, and length gain were $41.63 \mathrm{~g}$ and $9.86 \mathrm{~cm}$, respectively.

KEYWORDS: rajadanu; heritability; response; growth; genetic gain

\section{PENDAHULUAN}

Ikan mas rajadanu mempunyai potensi untuk dikembangkan dan dapat memberikan kontribusi ekonomi yang cukup besar bagi pembudidaya (Gustiano, 1998). Evaluasi dan karakteristik morfologi ikan mas rajadanu sudah lama dilakukan. Di Indonesia, kegiatan pemuliaan ikan mas khususnya selective breeding telah dimulai sejak tahun 1991 (Nugroho \& Wahyudi, 1991) dengan mengkoleksi 21 strain lokal dari berbagai daerah dengan topografi terisolasi (sanin Payakumbuh, mageg Sumatera Barat, pare, majalaya, rajadanu Kuningan, sutisna Kuningan, wildan Cianjur,

\# Korespondensi: Balai Penelitian dan Pengembangan Budidaya Air Tawar. Jl. Sempur No. 1, Bogor 16151, Indonesia. Tel.: + (0251) 8313200

E-mail: deniradona_kkp@yahoo.com aki endang Cianjur, sinyonya Pandeglang, ooh Cianjur, Sukabumi, domas topi haji, domas kancra, lokal Bogor, lokal Subang, karper kaca, punten, Jember, Cangkringan dan strain Bali). Evaluasi karakteristik reproduksi dan morfologi menunjukkan strain rajadanu, wildan Cianjur, sutisna Kuningan, dan majalaya mempunyai potensi untuk dikembangkan (Hardjamulia et al., 1996; Aliah \& Taniguchi, 1999). Sejak tahun 2000, ikan mas rajadanu digunakan sebagai populasi dasar untuk program seleksi (populasi sintetis) di Indonesia dan Thailand, serta kegiatan pembenihan dalam meningkatkan nilai produksi di Subang, Jawa Barat.

Ikan mas rajadanu memiliki morfologi bentuk badan yang panjang dan mempunyai ciri khusus berwarna hijau. Secara molekuler, marka genetik ikan mas rajadanu memiliki kekerabatan yang jauh dengan 
ikan mas koleksi lainnya (majalaya, sutisna Kuningan, magek, Bali, dan punten) dan cenderung dekat dengan ikan mas strain sinyonya dan wildan Cianjur. Selain unggul dari Ikan mas koleksi yang lain (majalaya, sutisna Kuningan, magek Bali, dan punten), ikan mas rajadanu mempunyai sekuensing molekuler marka genetik dan pilogenik berbeda dengan ikan Asia (common carp) lainnya yang berasal dari Vietnam, Thailand, Jepang, Uzbekistan, dan Cina (Thai et al., 2006; Dey et al., 2013). Uji pertumbuhan dalam pembentukan populasi sintentik di India dan Thailand menunjukan ikan mas rajadanu memiliki fenotipik yang unggul dibandingkan ikan asia lainnya (Nguyen, 2008).

Pada penelitian Asih et al. (2011), populasi dasar ikan mas rajadanu terbentuk sebanyak 36 famili pada tahun 2008, diperoleh 23 famili terbaik dan individu terbaik (combaining selection) dengan hasil sebanyak 34 ekor jantan 284 ekor betina sedangkan populasi F-2 terbentuk sebanyak 43 famili. Hasil seleksi F-2 selama dua generasi menunjukkan nilai heritabilitas sebesar 0,29; nilai koefisien keragaman (CV) sebesar $39,08 \%$; respons seleksi sebesar $43,36 \%$; dan genetic gain $(\mathrm{g})$ sebesar $35,2 \mathrm{~g}$ atau $23,8 \%$. Dari data hasil penelitian dapat diprediksi bahwa pertumbuhan ikan mas rajadanu pada pembentukan generasi selanjutnya bisa ditingkatkan lagi. Seleksi diharapkan dapat meningkatkan mutu genetik (genetic gain) yang lebih baik dan peningkatan tersebut tergantung dari proporsi ragam genetik terhadap ragam fenotipik yang diwariskan tetuanya (heritabilitas). Nilai proporsi angka pewarisan (heritabilitas) secara tepat dapat diketahui melalui kegiatan seleksi dari generasi ke generasi secara berkesinambungan (Falconer, 1981; Kapuscinski, 1987; Warwick et al., 1995). Sehingga hasil seleksi ikan mas rajadanu diharapkan dapat mendukung peningkatan produksi melalui perbaikan mutu benih dan induk. Penelitian ini dilakukan untuk mengevaluasi karakter reproduksi dan seleksi sifat pertumbuhan, respons seleksi dan heritabilitas ikan mas rajadanu F-3.

\section{BAHAN DAN METODE}

Penelitian dilakukan di Instalasi Penelitian Plasma Nutfah Perikanan Air Tawar Cijeruk, Balai Penelitian dan Pengembangan Budidaya Air Tawar, Bogor. Kegiatan ini meliputi pemijahan dan dilanjutkan dengan pendederan famili secara terpisah. Pemijahan yang dilakukan yaitu membentuk 25 famili yang terdiri atas tujuh famili half-sib, terdiri atas empat betina yang dibuahi satu jantan (Gambar 1). Induk yang digunakan adalah ikan mas rajadanu hasil seleksi F-2 yang berumur 18 bulan dengan ukuran bobot $(1.000,0 \pm$ $200,0 \mathrm{~g})$ dan panjang $(29,0 \pm 4,0 \mathrm{~cm})$. Seleksi induk matang gonad dilakukan secara kanulasi untuk mengetahui diameter oosit, sebaran dan posisi inti.
Pemijahan dilakukan dengan rangsangan hormon LhRH analog (ovaprim) dengan dosis $0,6 \mathrm{~mL} / \mathrm{kg}$ untuk betina dan $0,3 \mathrm{~mL} / \mathrm{kg}$ untuk jantan. Untuk memperoleh ovulasi berurutan secara bertahap dilakukan penyuntikan hormon dengan interval waktu lima menit setiap individu sesuai dengan urutan kode tagging dan skema pemijahan. Proses stripping dilakukan dalam satu hari yang sama. Telur yang telah dibuahi ditebar dikakaban dan ditetaskan dalam kolam ukuran 1,5 m x $1 \mathrm{~m}$ dengan ketinggian air $30 \mathrm{~cm}$. Pada fase pendederan, pemeliharaan benih dilakukan selama 160 hari. Pemeliharaan dilakukan pada kolam yang sama dengan ketinggian air $60 \mathrm{~cm}$. Selama pemeliharaan benih ikan mas rajadanu diberi pakan dengan frekuensi dua kali sehari. Pakan yang diberikan disesuaikan dengan usia dan ukuran (tipe dan jenis berbeda). Pada umur 3-30 hari benih diberi pakan berupa Artemia secara at-satiation, 31-60 hari diberi pakan berupa Dhapnia secara at-satiation, 61-100 hari diberi pakan pelet komersil berupa crumblle yang mengandung protein sebesar $32 \%$ secara ad-libitum dan umur $>100$ hari benih diberi pakan berupa pelet komersil $(3 \mathrm{~mm}$ ) yang mengandung $28 \%$ protein sebanyak $5 \%$ dari bobot total. Parameter yang diamati: pertumbuhan bobot dan panjang, respons seleksi, koefisien keragaman (CV), diferensial seleksi, dan nilai heritabilitas. Pengamatan pertumbuhan ikan dilakukan dengan mengukur (panjang dan bobot) sebanyak 30 ekor dari setiap populasi. Parameter pertumbuhan bobot dan panjang dihitung berdasarkan rumus menurut Effendi (1979) dan Murtidjo (2001), sedangkan parameter respons seleksi, koefisien keragaman, dan heritabilitas dihitung berdasarkan rumus menurut Gjedrem (2005).

\section{HASIL DAN BAHASAN}

\section{Karakter Reproduksi Ikan Mas Rajadanu}

Karakteristik reproduksi dari proses pemijahan 25 famili ikan mas rajadanu F-2 dan empat famili dari ikan mas rajadanu F-1 yang digunakan sebagai pembentuk populasi kontrol, meliputi: bobot induk, fekunditas, indeks ovo somatik (IOS), derajat pembuahan, derajat penetasan, dan sintasan disajikan pada Tabel 1.

Dari 28 ekor induk betina ikan mas rajadanu hasil seleksi F-2 yang dilakukan proses pemijahan hanya 25 ekor betina yang ovulasi dengan nilai tingkat ovulasi $100 \%$. Fekunditas yang dihasilkan sebanyak $126.972 \pm 51.074$ butir per ekor, rata-rata per gram berkisar 548-620 butir dengan diameter telur sebesar 1,0-1,2 mm. Nilai IOS (indeks ovo somatik) rata-rata sebesar $12,97 \pm 4,57 \%$. Secara umum nilai karakter reproduksi yang diperoleh dari induk ikan mas rajadanu F-2 (pembentuk F-3) lebih tinggi dibandingkan induk ikan mas F-1 (pembentuk F-2). Berdasarkan uji 


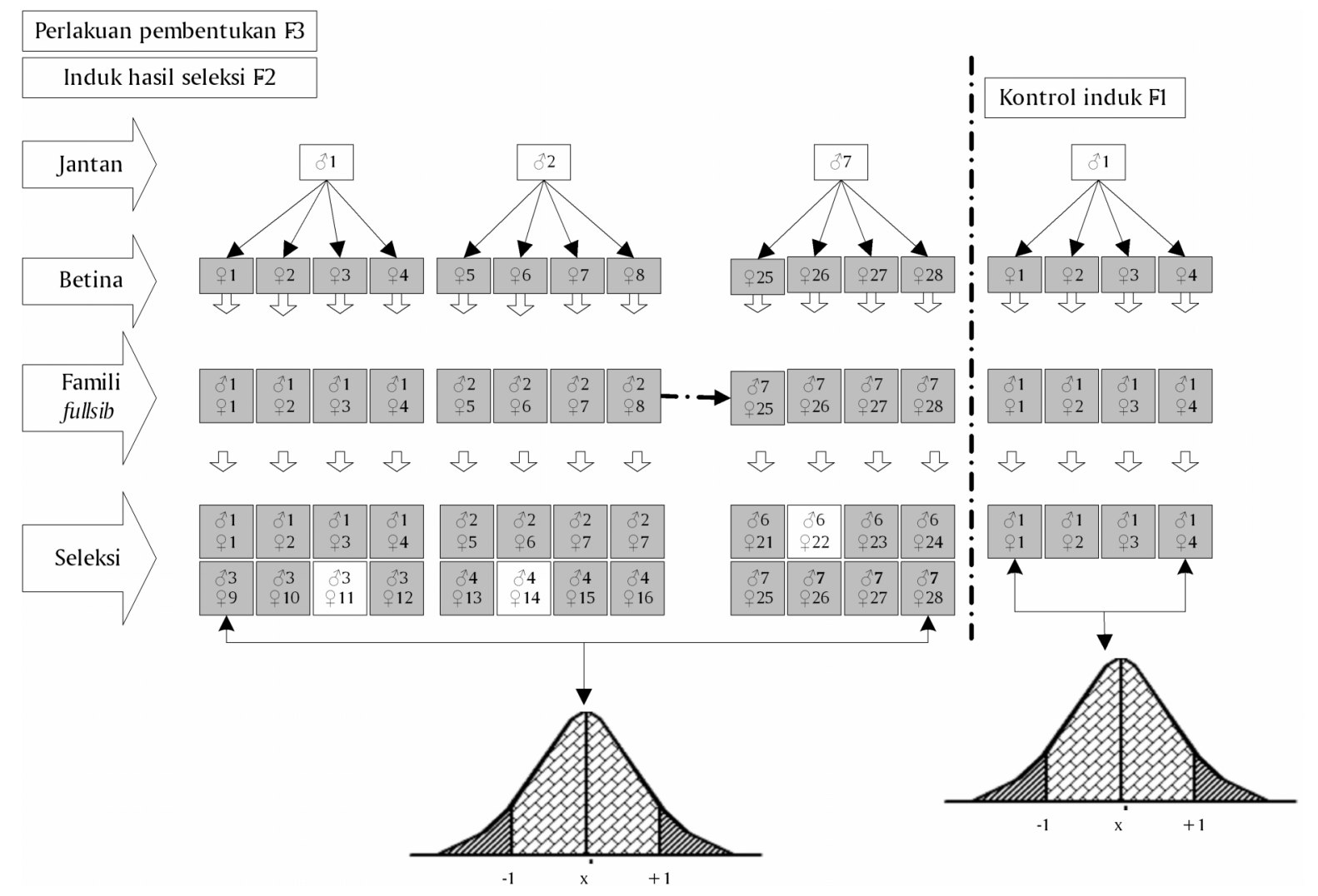

Gambar 1. Skema pemijahan ikan mas rajadanu secara half-sib

Figure 1. Spawning design of rajadanu carp by half-sib method

Tabel 1. Karakteristik reproduksi induk ikan mas rajadanu

Table 1. Characteristic of the reproductive performance of rajadanu carp broodstock

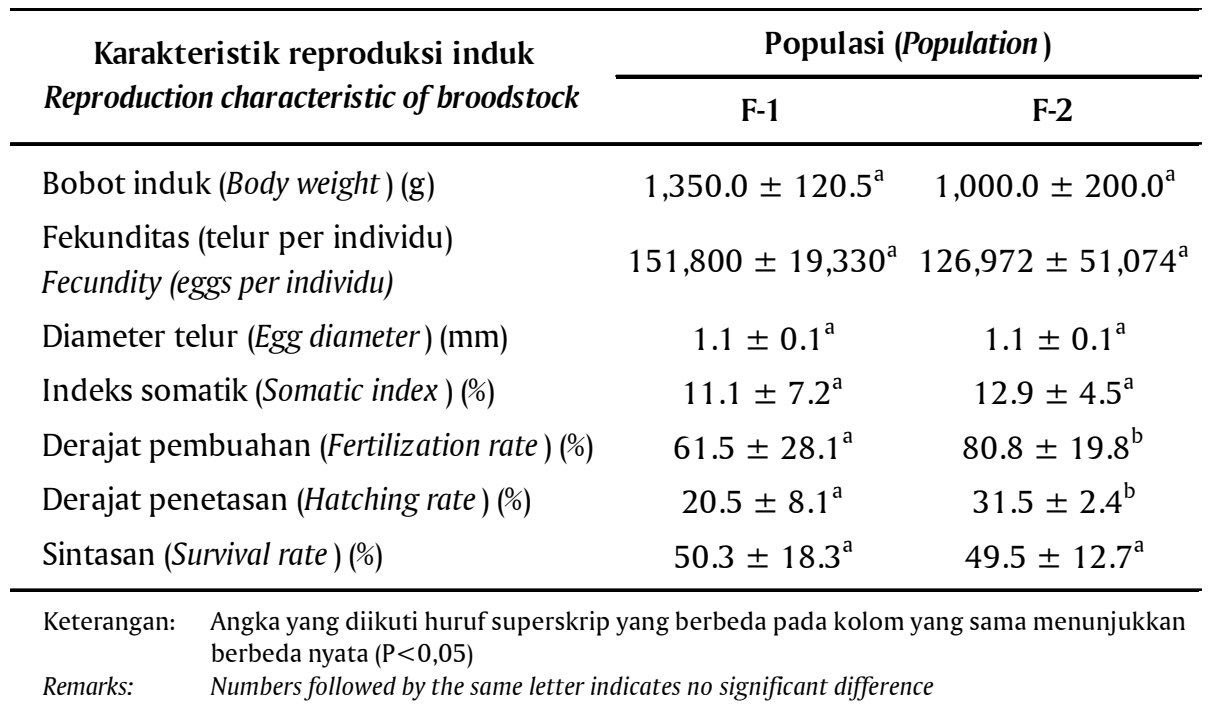


statistik dari parameter reproduksi yang terukur, parameter derajat pembuahan, dan derajat penetasan yang memiliki nilai yang berbeda nyata $(P<0,05)$. Menurut Bromage et al. (1993), faktor penting yang berpengaruh terhadap telur (jumlah dan ukuran) adalah ukuran dari induk yang digunakan. Semakin besar atau berat ukuran induk ikan semakin meningkatkan nilai fekunditasnya. Evaluasi reproduksi ikan mas 21 strain yang dilakukan Hardjamulia et al. (1996) menyatakan bahwa ikan mas rajadanu mempunyai diameter telur yang relalif lebih besar dibandingkan ikan mas lokal lainnya seperti: majalaya, wildan Cianjur, dan cangkringan yaitu sebesar 1,1-1,2 mm dengan fekunditas sebesar $600 \pm 54$ butir per gram. IOS pada induk ikan mas rajadanu F-2 mengalami sedikit peningkatan sebesar $1,8 \%$ dibandingkan dengan IOS pada induk ikan mas rajadanu F-1. Nilai IOS tersebut tidak jauh berbeda dengan IOS pada ikan mas majalaya dengan kisaran 12\%-15\% (Ath-thar et al., 2012). Meningkatnya IOS diduga nutrien pakan buatan dalam proses pematangan gonad dapat terpenuhi secara kontinu dengan kebutuhan protein yang cukup (28\%). Hal ini menunjukkan bahwa induk ikan mas rajadanu hasil seleksi mempunyai karakter reproduksi yang relatif sama dengan karakter tetuanya. Karakter reproduksi khususnya derajat penetasan dan sintasan pada ikan mas rajadanu terbilang rendah $(<50 \%)$. Derajat pembuahan (FR) dari hasil contoh telur dikakaban setelah 10 jam pembuahan (fase morula) sebesar $80,8 \pm 19,8 \%$ dan derajat penetasan (HR) sebesar 31,5 $\pm 2,4 \%$. Viabilitas atau sintasan (SR) larva pada umur tujuh hari selama pemeliharaan di kolam sebesar 50\% dengan rata-rata jumlah benih sebesar 10.000 ekor. Nilai reproduksi yang diperoleh menunjukkan kemampuan sifat yang diturunkan dari tetuanya. Pada penelitian ini, lingkungan untuk penetasan telur dan sintasan mempunyai kondisi yang sama, yaitu: suhu $\left(22^{\circ} \mathrm{C}-27^{\circ} \mathrm{C}\right)$ dan $\mathrm{pH}(6-7)$. Menurut Falconer (1981), sifat fenotipe dari suatu organisme dipengaruhi oleh tiga faktor: genotipe, lingkungan, dan interaksi keduanya.

\section{Respons Seleksi dan Heritabilitas}

Respons seleksi merupakan indikator keberhasilan dari program seleksi, semakin besar nilainya maka semakin besar pula keberhasilan dalam program seleksi. Berdasarkan seleksi yang dilakukan pada populasi ikan mas rajadanu F-3 yang dipelihara di kolam selama 160 hari diperoleh nilai diferensial seleksi (S), respons seleksi $(\mathrm{R})$, dan heritabilitas $\left(\mathrm{h}^{2}\right)$ pada karakter panjang dan bobot sesuai Tabel 2 .

Nilai respons seleksi dipengaruhi oleh beberapa faktor, di antaranya heritabilitas karakter yang terseleksi dan diferensial seleksi (Falconer, 1981). Seleksi yang dilakukan pada populasi ikan mas rajadanu F-3 memberikan nilai respons seleksi sebesar $14,20 \mathrm{~g}$ dengan nilai heritabilitas sebesar 0,60. Nilai heritabilitas tersebut mengindikasikan diperolehnya nilai respons yang positif dari program seleksi (Gjedrem, 2005; Nielsen et al., 2010) dan ini merupakan capaian yang sangat berarti dalam sistem budidaya ikan mas. Menurut Tave (1999), heritabilitas digolongkan menjadi tiga, yaitu rendah $(<0,2)$; sedang $(0,2-0,4)$; dan tinggi $(>0,4)$. Pada seleksi ikan mas rajadanu ini diperoleh nilai heritabilitas yang tinggi dan diharapkan berkorelasi positif terhadap respons seleksi yang akan diperoleh pada generasi selanjutnya (Vandeputte et al., 2008; Ninh et al., 2013). Pengamatan terhadap pertambahan nilai bobot rata-rata pada populasi ikan mas rajadanu F-3 menghasilkan nilai koefisien variasi (CV) sebesar 25,24\%; nilai tersebut tergolong sedang yaitu kisaran 20\%-50\%. Nilai koefisien variasi menunjukkan nilai keragaman fenotipik dari populasi yang terukur, di mana semakin tinggi nilai koefisien variasi semakin luas keragaman yang dimiliki atau lebih heterogen. Nilai variasi lebih dipengaruhi oleh generasi dan lingkungan (Ninh et al., 2011). Keragaman fenotipik berbanding lurus dengan keragaman genetik. Menurut Dunham (2004), ragam genetik penting untuk kelestarian jangka panjang suatu spesies atau populasi sehingga memungkinkan kemampuannya beradaptasi terhadap perubahan

Tabel 2. Diferensial seleksi, respons seleksi, koefisien keragaman, dan heritabilitas pada populasi ikan mas rajadanu F-3

Table 2. Differential selection, respons selection, covarian, and heritibility on F-3 carp rajadanu

\begin{tabular}{lc}
\hline \multicolumn{1}{c}{ Parameter (Parameters) } & Nilai (Value) \\
\hline Diferensial seleksi (Differential selection) $(\mathrm{g})$ & 23.35 \\
Respons seleksi (Responses selection) $(\mathrm{g})$ & 14.2 \\
Koefisien keragaman (Covarian) & 25.24 \\
Heritabilitas (Heritability) & 0.6 \\
\hline
\end{tabular}


lingkungan. Lebih lanjut dinyatakan, apabila ragam fenotipe sangat sempit maka akan ditemukan kendala dalam proses seleksi. Seleksi dapat meningkatkan mutu genetik secara kuantitatif dengan sasaran akhir memperoleh induk unggul sebagai tetua (Warmick et al., 1995; Gjedrem et al., 2012).

\section{Pertumbuhan Ikan Mas Rajadanu F-3}

Setelah pemeliharaan larva dilanjutkan ke tahap pendederan. Pendederan dilakukan dengan menggunakan kolam yang sama (1,5 $\mathrm{m}$ x $1 \mathrm{~m})$ dengan ketinggian air $60 \mathrm{~cm}$. Setiap kolam ditebar benih sebanyak 1.000 ekor. Selama 160 hari pemeliharaan diperoleh benih ikan mas rajadanu F-3 berukuran bobot rata-rata sebesar 41,63 $\pm 10,51 \mathrm{~g}$. Dari karakter pertumbuhan bobot tersebut, terseleksi tujuh famili dari 25 famili ikan mas rajadanu F-3 yang terbentuk. Seleksi dilakukan karena nilai bobot rata-rata populasinya di atas nilai bobot rata-rata seluruh populasi $(41,63 \mathrm{~g})$. Nilai bobot rata-rata populasi dari setiap famili dapat dilihat pada Gambar 2 .

Adapun nilai rata-rata pertambahan panjang dan bobot benih ikan mas rajadanu (Cyprinus carpio) F-3 selama 160 hari pemeliharaan disajikan pada Tabel 3 dan 4 .

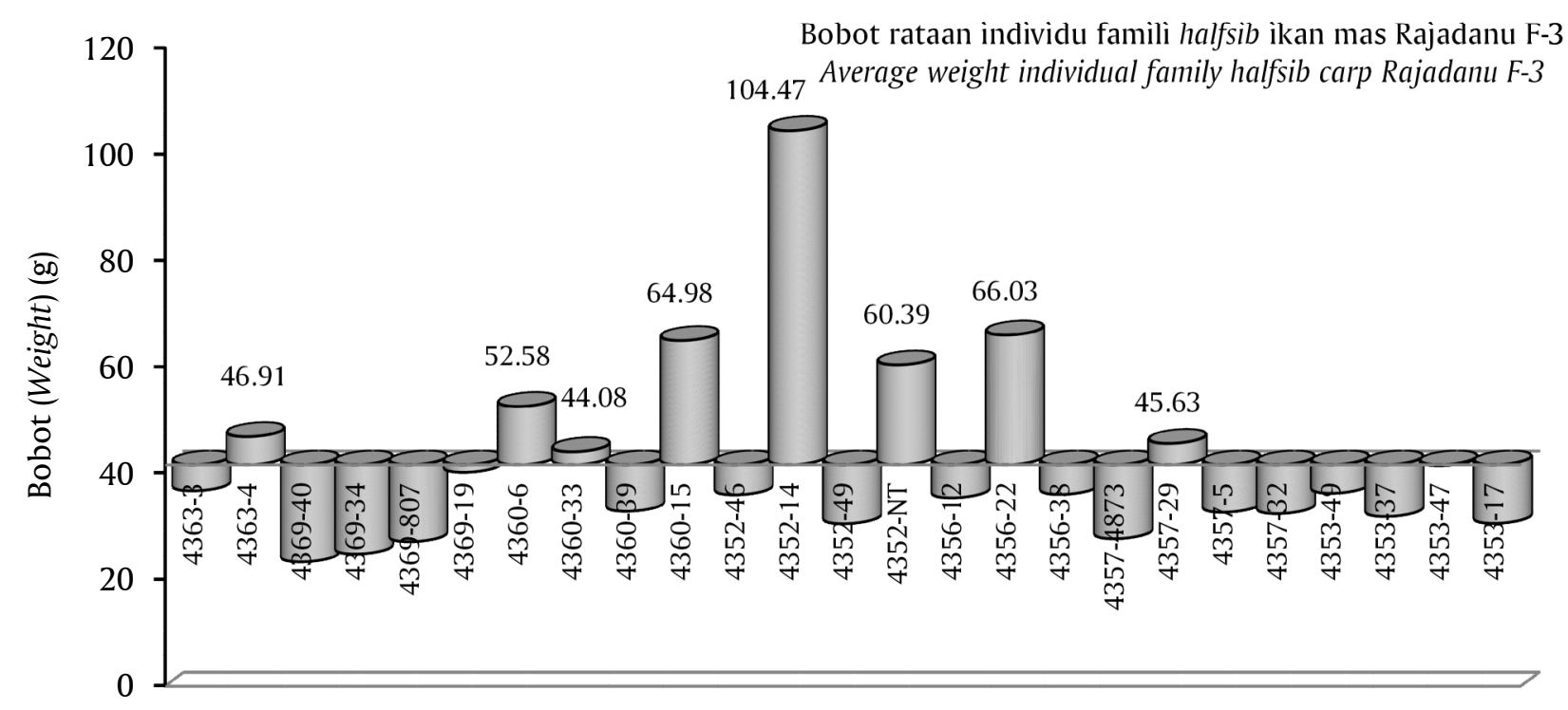

Famili (Family)

Gambar 2. Grafik famili terbaik yang terseleksi dari populasi F-3 ikan mas rajadanu

Figure 2. Graph of best family of selected from F-3 populations of rajadanu carp

Tabel 3. Pertumbuhan panjang standar benih ikan mas rajadanu F-3 selama 160 hari pemeliharaan

Table 3. The growth in standard length of F-3 rajadanu carp seed reared for 160 days

\begin{tabular}{|c|c|c|}
\hline \multirow{2}{*}{$\begin{array}{l}\text { Waktu pemeliharaan (hari) } \\
\text { Maintenance time (days) }\end{array}$} & \multicolumn{2}{|c|}{$\begin{array}{l}\text { Pertumbuhan panjang } \\
\text { Growth in length }(\mathrm{cm})\end{array}$} \\
\hline & F-2 (kontrol/control) & F-3 \\
\hline 0 & $0.00 \pm 0.00$ & $0.00 \pm 0.00$ \\
\hline 40 & $1.54 \pm 0.07^{\mathrm{a}}$ & $1.82 \pm 0.12^{\mathrm{a}}$ \\
\hline 80 & $3.44 \pm 1.37^{\mathrm{a}}$ & $4.30 \pm 1.23^{\mathrm{b}}$ \\
\hline 120 & $6.18 \pm 1.83^{\mathrm{a}}$ & $6.81 \pm 1.32^{\mathrm{a}}$ \\
\hline 160 & $8.47 \pm 2.00^{\mathrm{a}}$ & $9.86 \pm 1.43^{b}$ \\
\hline
\end{tabular}

Keterangan: Angka yang diikuti huruf superskrip yang berbeda pada kolom yang sama

Remarks: $\quad$ Numbers followed by the same letter indicates no significant difference 
Tabel 4. Pertumbuhan bobot benih ikan mas rajadanu F-3 selama 160 hari pemeliharaan

Table 4. The growth in weight of F-3 rajadanu carp seed reared for 160 days

\begin{tabular}{|c|c|c|c|}
\hline \multirow{2}{*}{\multicolumn{2}{|c|}{$\begin{array}{l}\text { Waktu pemeliharaan (hari) } \\
\text { Maintenance time (days) }\end{array}$}} & \multicolumn{2}{|c|}{$\begin{array}{l}\text { Pertumbuhan bobot } \\
\text { Growth weight (g) }\end{array}$} \\
\hline & & F-2 (kontrol/control) & F-3 \\
\hline & 0 & $0.00 \pm 0.00$ & $0.00 \pm 0.00$ \\
\hline & 40 & $0.14 \pm 0.01^{\mathrm{a}}$ & $0.23 \pm 0.06^{\mathrm{b}}$ \\
\hline & 80 & $2.89 \pm 0.44^{\mathrm{a}}$ & $4.29 \pm 0.23^{\mathrm{a}}$ \\
\hline & 120 & $12.33 \pm 3.81^{\mathrm{a}}$ & $15.24 \pm 4.32^{\mathrm{b}}$ \\
\hline & 160 & $27.43 \pm 9.95^{\mathrm{a}}$ & $41.63 \pm 10.5^{\mathrm{b}}$ \\
\hline Keterangan: & $\begin{array}{l}\text { Angka yang diikuti hur } \\
\text { menunjukkan berbeda }\end{array}$ & $\begin{array}{l}\text { superskrip yang berbeda } p \\
\text { ata }(P<0,05)\end{array}$ & kolom yang sama \\
\hline Remarks: & Numbers followed by the & me letter indicates no signific & at difference \\
\hline
\end{tabular}

Berdasarkan data Tabel 3 dan 4, menunjukkan pertumbuhan ikan mas rajadanu F-3 selama 160 hari pemeliharaan lebih tinggi dibandingkan dengan ikan mas rajadanu F-2. Benih ikan mas rajadanu F-3 memiliki pertumbuhan panjang dan bobot rata-rata individu sebesar $9,86 \mathrm{~cm}$ dan $41,63 \mathrm{~g}$; di mana nilai pertumbuhannya lebih besar dibandingkan ikan mas rajadanu F-2 yang hanya memperoleh nilai sebesar 8,47 $\mathrm{cm}$ dan 27,43 g. Secara statistik (Uji T) nilai tersebut menunjukkan perbedaan yang nyata $(\mathrm{P}<0,05)$. Secara genetic gain terdapat peningkatan sekitar $14,20 \mathrm{~g}$ atau sebesar 51\% (Gambar 3). Persentase peningkatan pertumbuhan yang terjadi menggambarkan tingginya variasi fenotipe pada populasi ikan mas rajadanu. Tingginya variasi fenotipe berkorelasi positif dengan variasi genetik (Tave, 1999; Noor, 2000). Tingginya variasi genotipe dapat memberikan peluang peningkatan laju pertumbuhan pada organisme.

\section{KESIMPULAN}

Karakter reproduksi dan seleksi sifat pertumbuhan F-3 lebih baik dibanding F-2 dengan peningkatan pertumbuhan $(51 \%)$; respons seleksi $(14,20 \mathrm{~g})$; dan heritabilitas $(0,60)$.

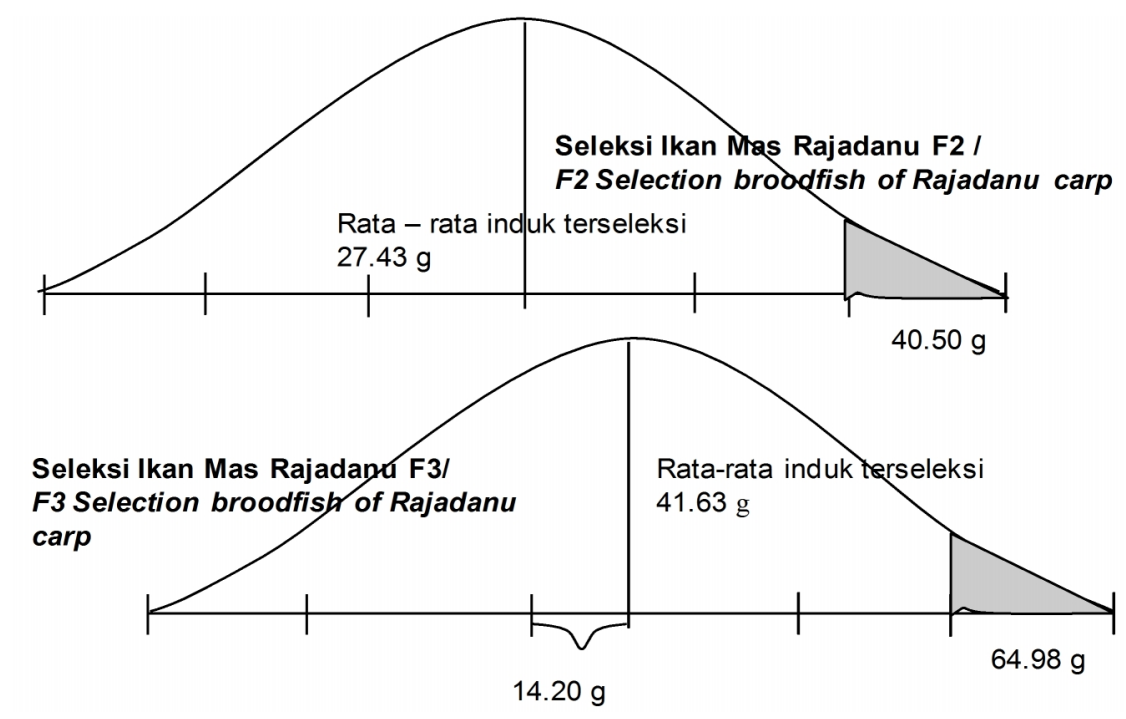

Gambar 3. Skema gambar seleksi ikan mas rajadanu F-3

Figure 3. Schematic figure of selection for F-3 rajadanu carp 


\section{UCAPAN TERIMA KASIH}

Ucapan terima kasih disampaikan kepada Balai Penelitian dan Pengembangan Budidaya Air Tawar, Bogor karena sudah mendanai kegiatan ini melalui APBN 2012 dan kepada semua pihak yang sudah terlibat dalam kegiatan ini.

\section{DAFTAR ACUAN}

Aliah, R.S., \& Taniguchi, N. (1999). Comparison of genetic variability in nine domesticated stocks of Indonesian common carp using microsatellite DNA markers. Fish Genetics and Breeding, 28, 121130.

Asih, S., Ath-thar, M.H.F., \& Kristanto, A.H. (2011). Pembentukan ikan mas rajadanu generasi 2 melalui seleksi famili. Prosiding Forum Inovasi Teknologi Akuakultur. Pusat Penelitian dan Pengembangan Perikanan Budidaya. Jakarta.

Ath-thar, M.H.F., Prakoso, V.A., \& Cahyanti, W. (2012). Keragaan reproduksi ikan mas strain Rajadanu, Subang, Majalaya dan lokal Kuningan. Buletin Litbang Budidaya Air Tawar, 1(2), 153-159.

Bromage, N., Randall, C., Duston, J., Thursh, M., \& Jones, J. (1993). Environmental control of reproduction in salmonids. In Muir, J., \& Roberts, R. (Eds.), Recent advances in aquaculture. Vol. IV. Blackwell Science. Oxford, p. 55-66.

Day, M.M., Kumar, P., Chen, O.I., Khan, M.A., Barik, N.K., Li, L., Nissapa, A., \& Pham, N.S. (2013). Potential impact of genetically improved carp strains in Asia. Elsevier (Food Policy), 43, 306-320.

Dunham, R.A. (2004). Aquaculture and fisheries biotechnology: Genetic Approach, CABI Publishing, Cambridge. USA, p. 85-99.

Effendie, M.I. (1979). Metode biologi perikanan. Yayasan Dewi Sri. Bogor, 258 hlm.

Falconer, D.S., \& Mackay, T.F.C. (1981). Introduction to quantitative genetics. Longman. New York. 2nd ed. USA, $438 \mathrm{pp}$.

Gjedrem, T., Robinson, N., \& Rye, M. (2012). The importance of selective breeding in aquaculture to meet future demands for animal protein: a review. Aquaculture, 350-353, 117-129.

Gjedrem, T. (2005). Selection and breeding programs. Springer. Netherland, $361 \mathrm{pp}$.

Gustiano, R., Hardjamulia, A., \& Rukyani, A. (1998). Carp genetic research and breeeding practices in Indonesian. IARD Journal, 20, 19-24.

Hardjamulia, A., Asih, S., Hambali, S., \& Baden, M. (1996). Karakterisasi morfologi dan evaluasi reproduksi beberapa plasma nutfah ikan mas (Cyprinus carpio). Bulletin Plasma Nutfah, 11(1).

Kapuscinski, A., \& Jacobson, L.D. (1987). Genetic guideline for fisheries management. University of Minnesota, USA.

Murtidjo, B.A. (2001). Beberapa metode pembenihan ikan air tawar. Kanisius. Yogyakarta, $108 \mathrm{hlm}$.

Noor, R.R. (2000). Genetika ternak. Penebar Swadaya. Jakarta, $200 \mathrm{hlm}$.

Nugroho, E., \& Wahyudi, N.A. (1991). Seleksi berbagai ras ikan mas koleksi dari berbagai daerah di Indonesia dengan menggunakan "skor z". Bull. Penel. Perik Darat, 10(2), 49-54.

Nguyen, T.T. (2008). Genetic improvement of carp reduces poverty, hunger in Asia. Worldfish Center. Penang, Malaysia.

Nielsen, H.M., Odegard, J., Olesen, I., Gjerde, B., Ardo, L., Jeney, G., \& Jeney, Z. (2010). Genetic analysis of common carp (Cyprinus carpio) strains: Genetic parameters and heterosis for growth traits and survival. Aquaculture, 304, 14-21.

Ninh, N.H., Ponzoni, R.W., Nguyen, H.N., Woolliams, J.A., Taggart, J.B., McAndrew, B.J., \& Penman, D.J. (2013). A comparison of communal and separate rearing of families in selective breeding of common carp (Cyprinus carpio): Responses to selection. Aquaculture, 408-409, 152-159.

Ninh, N.H., Ponzoni, R.W., Nguyen, H.N., Woolliams, J.A., Taggart, J.B., McAndrew, B.J., \& Penman, D.J. (2011). A comparison of communal and separate rearing of families in selective breeding of common carp (Cyprinus carpio). Aquaculture, 322, 3946.

Tave, D. (1999). Inbreeding and broodstock management. Fisheries Technical Paper No. 392 ed. FAO. Rome, 122 pp.

Thai, B.T., Pham, T.A., \& Austin, C.M. (2006). Genetic diversity of common carp in Vietnam using direct sequencing and SSCP analysys of the mitochondrial DNA control region. Aquaculture, 258, 228-240.

Vandeputte, M., Kocour, M., Mauger, S., Rodina, M., Launay, A., Gela, D., Dupont-Nivet., Hulak, M., \& Linhart, O. (2008). Genetic variation for growth at one and two summers of age in the common carp (Cyprinus carpio L): Heritability estimates and response to selection. Aquaculture, 277, 7-13.

Warwick, M., Astuti, W., \& Hardjosubroto. (1995). Pemuliaan ternak. Gajah Mada University Pers. Jogjakarta, 490 hlm. 